\title{
PHYSIOLOGICAL-BIOCHEMICAL PARAMETERS AND CHARACTERISTICS OF SEED COAT STRUCTURE IN LUPIN SEEDS SUBJECTED TO LONG STORAGE AT DIFFERENT TEMPERATURES
}

\author{
AGNIESZKA I. PIOTROWICZ-CIEŚLAK ${ }^{1}$, DARIUSZ J. MICHALCZYK ${ }^{1}$, \\ KAMILLA GÓRSKA ${ }^{1}$, ZOFIA BULIŃSKA-RADOMSKA ${ }^{2}$, RYSZARD J. GÓRECKI ${ }^{1}$ \\ ${ }^{1}$ Department of Plant Physiology and Biotechnology \\ University of Warmia and Mazury \\ Oczapowskiego 1A, 10-718 Olsztyn, Poland \\ e-mail: acieslak@uwm.edu.pl \\ 2 National Centre for Plant Genetic Resources, \\ Plant Breeding and Acclimatization Institute, Radzików, Poland
}

(Received: April 6, 2007. Accepted: August 6, 2007)

\begin{abstract}
Seed vigour, viability, the contents of soluble carbohydrates, total protein, albumins, and globulins, as well as seed coat structure, were analysed in yellow lupin (Lupinus luteus L.) cv. Iryd seeds stored for 20 years at $-14^{\circ} \mathrm{C}$, $0^{\circ} \mathrm{C}$ or at room temperature (approx. $+20^{\circ} \mathrm{C}$ ). Seed storage at room temperature reduced viability (to $2 \%$ ) and increased seed leachate electroconductivity. Determinations of total proteins showed that protein content was significantly reduced in seeds stored at $+20^{\circ} \mathrm{C}$ compared to the other storage regimens. Raffinose family oligosaccharides were the main soluble carbohydrates in seeds stored at $0^{\circ} \mathrm{C}$ and $-14^{\circ} \mathrm{C}$, whereas sucrose dominated in seeds stored at room temperature. Scanning electron microscopy (SEM) of seed surface and seed coat sections revealed appearance of an amorphic layer on the surface of seeds stored at room temperature (not observed in other seeds) and distinct shrinking of macrosclereid layer in seeds stored at $-14^{\circ} \mathrm{C}$. Macrosclereids layer in all seeds was 100 $\mu \mathrm{m}$ thick and accounted for $60 \%$ of seed coat thickness. The obtained results suggest that for long term storage of lupin seeds at $0^{\circ} \mathrm{C}$ is the most advisable temperature if both costs of storage and seed storability are considered.
\end{abstract}

KEY WORDS: lupin seeds, storability, proteins, soluble carbohydrates, seed surface, seed coat.

\section{INTRODUCTION}

During prolonged storage seeds undergo ageing, lose their biological potential (vigour, viability) and economic value, and eventually die. Considering seed longevity and storage physiology, seeds can be divided into three groups: 1) orthodox; 2) recalcitrant; 3) intermediate (Roberts 1973). Only members of the first group withstand long storage (many years) fairly well. On the other hand, the above classification is not very clear-cut (Ellis et al. 1990).

Orthodox seeds can retain viability, resting in the state of anabiosis, because they tolerate desiccation (down to the water content around 5-10\% dry weight). Nevertheless, even in seeds of high longevity, degenerative processes do occur during long storage, and they include lipid oxidation, membrane and DNA impairments, degradation of proteins and decrease of enzyme activities (Murthy et al. 2003). Ageing-related reduction of enzyme activity was observed in enzymes as essential as dehydrogenases of the Krebs cycle, cytochrom c oxidase, and malate and glutamate de- hydrogenases. Decline of enzyme activities is caused by enzyme protein denaturation (Roberts 1972). On the other hand, those dissimilative enzymes, the activity of which is not strongly reduced by seed ageing may contribute, together with non-enzymatic reactions, to uncontrolled breakdown of organic compounds in ageing seeds (Bewley and Black 1994). The objective of this work was to determine the effects of prolonged seed storage (for 20 years) at different temperatures on seed vigour, viability, chemical composition and seed coat microstructure.

\section{MATERIALS AND METHODS}

Seeds of yellow lupin (Lupinus luteus L), cv. Iryd were stored in tightly closed jars at $0^{\circ} \mathrm{C},-14{ }^{\circ} \mathrm{C}$ or under ambient laboratory conditions (approx. $+20^{\circ} \mathrm{C}$ ). At the beginning of the experiment (storage) seeds contained water at $8.8 \% \pm 0.1 \%$ of dry weight, as determined by the gravimetric method. After 20 years of storage, selected seed characteri- 
stics were studied: microstructure of seed coat surface and seed coat sections, physiological parameters and biochemical composition. Viability and vigour determinations were based on assays of germination capacity and measurements of seed leachate conductrometry, as recommended by ISTA (1999). Total protein content was determined with Bradford (1976) method. Albumins were isolated from $2 \mathrm{~g}$ seed in 10 ml extraction buffer $\left(0.1 \mathrm{M} \mathrm{KK_{2 }} \mathrm{PO}_{4}+0.1 \mathrm{M} \mathrm{NaOH}\right.$, pH 7.5), containing $0.4 \mathrm{M} \mathrm{NaCl}$ (Marcone et al. 1994). Globulins were extracted according to the method of Hall et al. (1977). The contents of soluble carbohydrates, cyclitols and galactosyl cyclitols were determined by gas chromatography (Piotrowicz-Cieślak 2005b). In analyses of seed coat microstructure, freshly harvested lupin seeds were used for comparisons (as control). Cross sections and surface of the testa were coated with gold (JEOL JFC 1200) and observed with scanning electron microscope JEOL JSM - 5310LV at 25kV (Piotrowicz-Cieślak 2005a).

\section{RESULTS}

\section{Seed vigour and viability}

Seeds stored at both $-14^{\circ} \mathrm{C}$ and $0^{\circ} \mathrm{C}$ germinated at similar rate -99 and $96 \%$, respectively (Table 1), whereas in seeds stored at room temperature percentage germination dropped severely - to $2 \%$. The conductometric assays confirmed different levels of seed deterioration (Table 1). Seeds stored at $-14^{\circ} \mathrm{C}$ and $0^{\circ} \mathrm{C}$ gave seed leachate electroconductivity nearly twice lower than seeds stored under room temperature.

\section{Seed protein}

The highest protein content was measured in seeds stored at $-14^{\circ} \mathrm{C}$ and $0^{\circ} \mathrm{C}$ (Table 2), whereas in seeds stored at $+20^{\circ} \mathrm{C}$ it was approx. $50 \%$ lower. Globulins made up 70 to $80 \%$ protein. In seeds stored at room temperature, both globulin and albumin contents were lower by approx. 50\%, compared to the other seeds.

\section{Carbohydrates}

The following carbohydrates could be identified on GC chromatograms of seed extracts (Table 3):

- raffinose family oligosaccharides: raffinose, stachyose, verbascose,

$$
\text { - galactosyl cyclitols: }
$$

TABLE 1. Germination [\%] and conductivity [ $\mu \mathrm{S} / \mathrm{g}$ seeds] of Lupinus luteus seeds stored at $0^{\circ} \mathrm{C},-14^{\circ} \mathrm{C}$ and room temperature $\left(\right.$ near $+20^{\circ} \mathrm{C}$ ) for 20 years.

\begin{tabular}{ccc}
\hline Storage conditions & Germination $\%$ & $\begin{array}{c}\text { Conductivity } \mu \mathrm{S} / \mathrm{g} \\
\text { of seeds }\end{array}$ \\
\hline$+20^{\circ} \mathrm{C}$ & $2 \pm 2$ & $795 \pm 24$ \\
$0^{\circ} \mathrm{C}$ & $96 \pm 2$ & $405 \pm 32$ \\
$-14^{\circ} \mathrm{C}$ & $99 \pm 1$ & $410 \pm 27$ \\
\hline
\end{tabular}

TABLE 2. Total protein, albumin and globulin contents [\% d.m.] in Lupinus luteus seeds stored at $0^{\circ} \mathrm{C},-14^{\circ} \mathrm{C}$ and room temperatures for 20 years.

\begin{tabular}{cccc}
\hline \multirow{2}{*}{$\begin{array}{c}\text { Storage } \\
\text { conditions }\end{array}$} & & $\%$ & \\
\cline { 2 - 4 } & Protein & Albumin & Globulin \\
\hline$+20^{\circ} \mathrm{C}$ & $18.24 \pm 3.3$ & $2.33 \pm 0.24$ & $14.21 \pm 0.57$ \\
$0^{\circ} \mathrm{C}$ & $33.57 \pm 2.5$ & $8.41 \pm 0.47$ & $24.95 \pm 1.26$ \\
$-14^{\circ} \mathrm{C}$ & $36.69 \pm 1.9$ & $8.26 \pm 0.52$ & $26.48 \pm 1.49$ \\
\hline
\end{tabular}

- myo-inositol series: - galactinol, digalacto-myo-inositol,

- pinitol A series: - galactopinitol A, ciceritol, trigalactopinitol A,

- pinitol B series: - galactopinitol B, digalactopinitol B, trigalactopinitol B;

- monosaccharides: fructose, glucose and galactose,

- sucrose,

- cyclitols: myo-inositol, D-pinitol, D-chiro-inositol.

Raffinose family oligosaccharides were the main soluble carbohydrates in seeds stored at $-14^{\circ} \mathrm{C}$ and $0^{\circ} \mathrm{C}$. Sucrose prevailed in seeds stored at $+20^{\circ} \mathrm{C}$. The level of RFO in the last mentioned seeds was about four times lower and the amount of sucrose three times higher, compared to seeds subjected to 'cold storage' $\left(-14^{\circ} \mathrm{C}\right.$ and $\left.0^{\circ} \mathrm{C}\right)$. The total carbohydrates level was similar in all seeds (Table 3 ). Similarly, all seeds, irrespective of the storage conditions, contained similar amounts of total galactosyl cyclitols $(12.4 \pm 0.1$ $\mathrm{mg} / \mathrm{g}$ d.m.). The galactosyl cyclitols composition differed however, across the seeds. Seeds stored at room temperature were characteristically poor in high molecular mass galactosyl cyclitols and contained high amounts of the simplest members of this metabolite group (i.e. galactinol, galactopinitol A, galactopintol B). Trigalactopinitol A (the largest of the molecules studied here) occurred in these seeds only at trace level. The contents of galactosyl cyclitols with intermediate molecular masses (i.e. ciceritol, digalacto-myo-inositol and digalactopinitol B) were also appreciably lower in seeds stored at room temperature, compared to those stored at $0^{\circ} \mathrm{C}$ and $-14^{\circ} \mathrm{C}$ (no differences in galactosyl cyclitol levels occurred across seeds subjected to both these 'cold storage' regimens). Seeds stored at room temperature were characterised by high level of reducing sugars and cyclitols (mainly D-chiro-inositol and myo-inositol). The sucrose/RFO ratio was the same $(0.26)$ across seeds subjected to cold storage $\left(0^{\circ} \mathrm{C}\right.$ and $\left.-14^{\circ} \mathrm{C}\right)$. This ratio was 15 times higher in seeds stored at $20^{\circ} \mathrm{C}$.

\section{Seed coat structure}

The following tissue layers could be identified on cross sections of seed coat (testa): macrosclereids, microsclereids, parenchyma cells (Fig. 1), with $100 \mu \mathrm{m}, 25 \mu \mathrm{m}$ and 50 $\mu \mathrm{m}$ thickness, respectively. Seed storage did not affect the thickness of tissue layers, however it did affect seed coat surface. In seeds stored at $0^{\circ} \mathrm{C}$ the macrosclereids aggregated in groups with irregular, polygonal sections and diameters above $10 \mu \mathrm{m}$, leaving empty spaces (pits), 2-3 $\mu \mathrm{m}$ wide. The appearance of macrosclereid layer in these seeds was practically indistinguishable from the macrosclereid layer of freshly harvested seeds. In testa of seeds stored at $-14^{\circ} \mathrm{C}$ macrosclereid groups had more irregular shapes and were more extended, whereas the pits were 1.5-3 times wider compared to such features of seeds stored at $0^{\circ} \mathrm{C}$. Testa surface of seeds stored at room temperature was characterised by the occurrence of an amorphic substance filling the pits between macrosclereid groups and - in some small areas - detaching the cell walls.

\section{DISCUSSION}

In order to withstand long storage, seeds should have low water content and their cells should adopt the glassy state. 
TABLE 3. Carbohydrates composition and contents [mg/g d.m.] in Lupinus luteus seeds stored at different temperature (data are expressed as the mean of 3-5 independent repeats \pm SD).

Temperature storage

\begin{tabular}{|c|c|c|c|}
\hline \multirow{2}{*}{ Carbohydrates } & & & \\
\hline & $+20^{\circ} \mathrm{C}$ & $0^{\circ} \mathrm{C}$ & $-14^{\circ} \mathrm{C}$ \\
\hline \multicolumn{4}{|c|}{ Raffinose family oligosaccharides } \\
\hline Raffinose & $3.87 \pm 0.24$ & $8.98 \pm 0.24$ & $8.67 \pm 0.36$ \\
\hline Stachyose & $18.97 \pm 1.53$ & $53.24 \pm 3.53$ & $52.57 \pm 3.57$ \\
\hline Verbascose & $\operatorname{tr}$ & $42.54 \pm 2.24$ & $42.27 \pm 1.92$ \\
\hline \multicolumn{4}{|c|}{ Galactosyl cyclitols } \\
\hline Galactinol & $2.34 \pm 0.09$ & $1.32 \pm 0.21$ & $1.25 \pm 0.24$ \\
\hline Digalacto-myo-inositol & $0.26 \pm 0.05$ & $0.79 \pm 0.07$ & $0.86 \pm 0.16$ \\
\hline Galactopinitol B & $2.34 \pm 0.31$ & $0.86 \pm 0.11$ & $0.87 \pm 0.09$ \\
\hline Digalactopinitol B & $0.37 \pm 0.27$ & $0.91 \pm 0.07$ & $0.97 \pm 0.10$ \\
\hline Trigalactopinitol B galac- & $\operatorname{tr}$ & $\operatorname{tr}$ & $\operatorname{tr}$ \\
\hline topinitol A & $4.56 \pm 0.37$ & $2.47 \pm 0.47$ & $2.34 \pm 0.33$ \\
\hline Ciceritol & $2.34 \pm 0.16$ & $3.37 \pm 0.33$ & $3.86 \pm 0.06$ \\
\hline Trigalactopinitol A & $\operatorname{tr}$ & $2.67 \pm 0.41$ & $2.37 \pm 0.18$ \\
\hline \multicolumn{4}{|c|}{ Monosaccharides and sucrose } \\
\hline Glucose & $4.23 \pm 0.51$ & $0.06 \pm 0.01$ & $0.07 \pm 0.02$ \\
\hline Fructose & $7.61 \pm 0.64$ & $0.67 \pm 0.03$ & $0.69 \pm 0.07$ \\
\hline Galactose & $5.34 \pm 0.34$ & $0.04 \pm 0.04$ & $\operatorname{tr}$ \\
\hline Sucrose & $88.24 \pm 6.57$ & $27.68 \pm 2.34$ & $26.98 \pm 1.97$ \\
\hline \multicolumn{4}{|c|}{ Cyclitols } \\
\hline D-pinitol & $1.69 \pm 0.68$ & $1.06 \pm 0.04$ & $1.01 \pm 0.06$ \\
\hline D-chiro-inositol & $0.67 \pm 0.07$ & $0.37 \pm 0.06$ & $0.36 \pm 0.08$ \\
\hline myo-inositol & $3.64 \pm 0.42$ & $1.98 \pm 0.27$ & $1.77 \pm 0.16$ \\
\hline Sum of RFO [mg/g] & 22.84 & 104.76 & 103.51 \\
\hline Sum of soluble sugars $[\mathrm{mg} / \mathrm{g}]$ & 146.47 & 149.01 & 146.91 \\
\hline Sucrose/RFO & 3.86 & 0.26 & 0.26 \\
\hline
\end{tabular}

The mode of water binding in seeds seems to be a very important factor for seed longevity, and it depends on temperature (Walters 2004). Three 'zones' of hydration level can be distinguished in starchy seeds: I (4-11\% water), II (12$-21 \%$ water) i III (22\% water and above). The level of seed hydration is the main determinant of seed damage at freezing temperatures $\left(-18^{\circ} \mathrm{C}\right.$ to $\left.-180^{\circ} \mathrm{C}\right)$ (Vertucci 1989$)$.

Within zone I, water is tightly bound to the surface of macromolecules. Such water, when cooled, does not form ice crystals. Seeds studied here had low hydration level $(8.8 \%)$, however, like soybean, lupin seeds are not 'starchy'. Hydration zone I for soybean has been determined and it is above $5 \%$, so seeds studied here could belong to hydration zone II. The glassy state adoption by seed cells is believed to inhibit the deteriorative processes by limiting the cytoplasm fluidity and mobility (Williams and Leopold 1989; Leprince and Walters-Vertucci 1995; Sun 1997). With increasing temperature and hydration level, seed cells undergo a transition to semi-liquid and liquid state, and it results in accelerated seed deterioration and decline of germination ability (Sun and Leopold 1993; Leopold et al. 1994). Raffinose family oligosaccharides are among the factors imposing the glassy state on seed cells (Buitink et al. 2000). These carbohydrates are accumulated in lupin seeds as their main storage compounds. Decreasing RFO levels correspond to accelerated seed ageing and seed viability depression (Tabs 1 and 3). Seeds stored at $+20^{\circ} \mathrm{C}$ accu- mulated high levels of sucrose and reducing sugars and this further raised sucrose/RFO ratio. Low sucrose/RFO ratio was described as characteristics of seeds with high longevity (Piotrowicz-Cieslak 2005). The results shown here suggest that in addition to RFO, high molecular weight galactosyl cyclitols may also condition lupin seeds storability.

During seed storage at room temperature the level of seed proteins, albumins and globulins, dropped (Table 2). Proteins are the main storage material in lupin seeds and they occur in lupin at record high level among legumes (Blanner et al. 2003). The amount of proteins is genetically determined, but strictly controlled by culture conditions, such as climate, soil, fertilizers and other agrotechnical factors. Thus, protein concentration in lupins is not steady (Faluyi et al. 2000; Erba et al. 2005). In experiments presented here, the highest protein content was detected in seeds stored at $-14^{\circ} \mathrm{C}$ and $0^{\circ} \mathrm{C}$, whereas in seeds stored at $20^{\circ} \mathrm{C}$ it was reduced by nearly $50 \%$. The main lupin proteins are globulins and albumins (Salmonowicz 2000). Both protein fractions deteriorate in seeds stored at $+20^{\circ} \mathrm{C}$. Globulins make up 60 to $80 \%$ of proteins (Erba et al. 2005), and serve mainly as storage material (Muntz et al. 2001; Shutov et al. 2003).

Albumins constitute up to $20 \%$ total protein and serve to a large extent as enzymes (Salmonowicz 2000). Storage of lupin seeds at room temperature did not affect the contents of either albumins or globulins, although it did decrease 

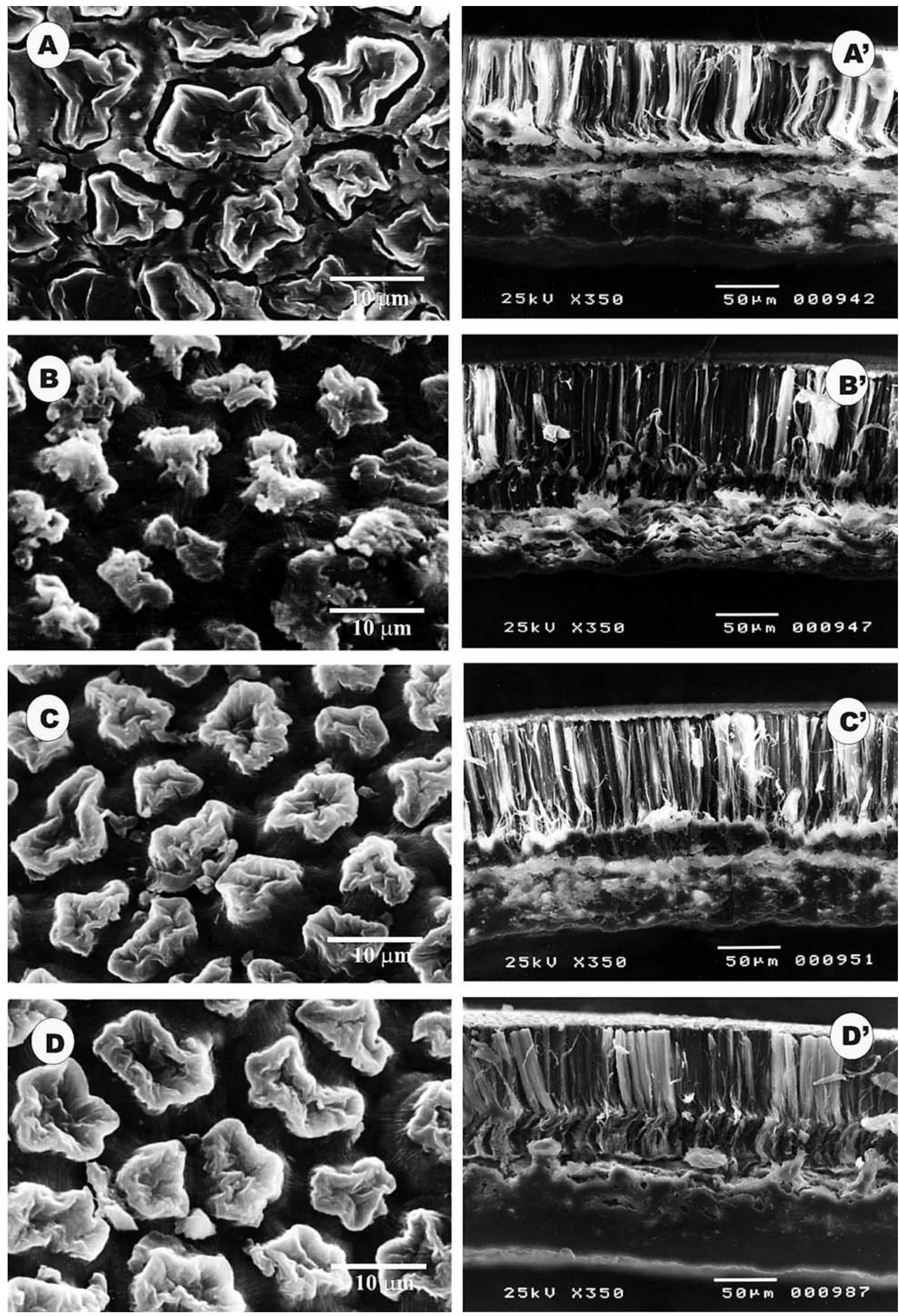

Fig. 1. Lupinus luteus cv. Iryd seed surface sculpture - scanning electron micrographs of seed surface (A, B, C, D) and cross sections (A', B', C', D') of the seed coat. A, A' - seeds stored for 20 years at room temperature (approx. $+20^{\circ} \mathrm{C}$ ); B, B' seeds stored for 20 years at $-14^{\circ} \mathrm{C} ; \mathrm{C}^{\prime} \mathrm{C}^{\prime}$ seeds stored for 20 years at $0^{\circ} \mathrm{C} ; \mathrm{D}, \mathrm{D}^{\prime}$ freshly harvested seeds. The bar shows the scale. 
their levels. The levels of these protein fractions in seeds stored at $-14^{\circ} \mathrm{C}$ and $0^{\circ} \mathrm{C}$ were very similar.

The obtained results show that although seeds stored at $-14^{\circ} \mathrm{C}$ and $0^{\circ} \mathrm{C}$ did not differ in physiological or biochemical characteristics, the ultrastructure of testa was different. In seeds stored at $-14^{\circ} \mathrm{C}$ the integrity of seed coat was lost to some extent (which is evident when micrographs of testa seeds stored at both $-14^{\circ} \mathrm{C}, 0^{\circ} \mathrm{C}$ and freshly harvested seeds are compared). The differences in seed coat structure between seeds stored at $0^{\circ} \mathrm{C}$ and $-14^{\circ} \mathrm{C}$ evidently did not affect the performance of these seeds. However, it is known, that testa fracture and excessive permeability can be destructive at the beginning of legume seed germination, as it leads to soaking injury (Bewley and Black 1994). Therefore, considering both economic reasons and observed initial symptoms of seed coat deterioration, $0^{\circ} \mathrm{C}$ rather than $-14^{\circ} \mathrm{C}$ seems to be the most suitable temperature for storage of lupin seeds over very long periods of time (over 20 years).

To our knowledge, no recommendations for such long storage of lupin seeds have been published so far. For medium duration storage (several years) of various seeds, it is advised to reduce their hydration level to $5 \%$ and the temperature to $0-5^{\circ} \mathrm{C}$. For long term storage of various seeds it is recommended to decrease their hydration level to $5 \%$ and the temperature to $-80^{\circ} \mathrm{C}$ or lower, even down to $-196^{\circ} \mathrm{C}$ (Stanwood and Sowa 1995). On the other hand, in some seeds such low storage temperatures are not necessary. Cereal (barley and oats) kernels stored in tightly closed containers at $10-15^{\circ} \mathrm{C}$ at low hydration level after 110 years retained high viability $(90 \%$ and $80 \%$, respectively; Steiner and Ruckenbauer 1996).

The seeds used in experiments reported here had $8.8 \%$ water content (conf. Materials and Methods). For this material, storage temperatures $-14^{\circ} \mathrm{C}$ and $0{ }^{\circ} \mathrm{C}$ seem equally good with respect to seed vigour, viability and chemical composition. Therefore both $0^{\circ} \mathrm{C}$ and $-14^{\circ} \mathrm{C}$ temperatures can be recommended for storage of lupin seeds over periods of up to 20 years, although, considering the economic factor (cost of storage), $0^{\circ} \mathrm{C}$ seems most advisable.

\section{LITERATURE CITED}

BEWLEY J.D., BLACK M. 1994. Seeds: physiology of development and germination. 2nd edition. New York (NY): Plenum Press. pp 445.

BLANNER J.L., FLENGMARK P., GYLLING M., ITENOV K. 2004. Lupin seed (Lupinus albus and Lupinus luteus) as a protein source for fermentation use. Industrial Crops and Products, 18 (3): 199-211.

BRADFORD M.M. 1976. A rapid and sensitive method for the quantitation of microgram quantities of protein utilizing the principle of protein-dye binding. Anal. Biochem. 72: 248-254.

BUITINK J., LEPRINCE O., HOEKSTRA F.A. 2000. Dehydration-induced redistribution of amphiphilic molecules between cytoplasm and lipids is associated with desiccation tolerance in seeds. Plant Physiol. 124: 1413-1426.

ELLIS R.H., HONG T.D., ROBERTS E.H. 1990. An intermediate category of seed storage behaviour? I. Coffee. J. Exp. Bot. 41: 11671174

ERBA M., CERTEL M., USLU M.K. 2005. Some chemical properties of white lupin seeds (Lupinus albus L.). Food Chem. 89 (3): 341-345.

FALUYI M.A., ZHOU X.M., ZHANG F., LEIBOVITCH S., MIGNER P., SMITH D.L. 2000. Seed quality of sweet white lu- pin (Lupinus albus) and management practice in eastern Canada. Eur. J. Agron. 13 (1): 27-37.

HALL T.C., McLEESTER R.C., BLISS F.A. 1977. Equal expression of the material and paternal loci for the polypeptide subunits of the major storage protein of the beans Phaseolus vulgaris L. Plant Physiol. 59: 1122-1124.

ISTA. (1999). International Rules for Seed Testing. Seed Sci. Technol. (Suppl.) 27: 1-333.

LEOPOLD A.C., SUN W.Q., BERNAL-LUGO I. 1994. The glassy state in seeds: analysis and function. Seed Sci. Res. 4: 267-274.

LEPRINCE O., WALTERS-VERTUCCI, C. 1995. A calorimetric study of the glass transition behaviors in axes of bean seeds with relevance to storage stability. Plant Physiol. 109: 1471-1481.

MARCONE M.F., FRANCIS K.N., MARC L.M., RICKEY V.Y. 1994. Purification and characterization of the physiochemical properties of albumin fraction from the seeds of Amaranthus hypochondriacus. Food Chem. 51: 287-294.

MUNTZ K., BELOZERSKY M.A., DUNAEVSKY Y.E., SCHLERETH A., TIEDEMANN J. 2001. Stored proteinases and the initiation of storage protein mobilization in seeds during germination and seedling growth. J. Exp. Bot. 52 (362): 1741-1752.

MURTHY U.M.N., KUMAR P.P., SUN W.Q. 2003. Mechanisms of seed ageing under different storage conditions for Vigna radiata (L.) Wilczek: lipid peroxidation, sugar hydrolysis, Maillard reactions and their relationship to glass state transition. J. Exp. Bot. 54: 1057-1067.

PIOTROWICZ-CIEŚLAK A.I. 2005a. Composition of seed soluble carbohydrates and ultrastructural diversity of testa in lupins from the Mediterranean region. Acta Soc. Bot. Pol. 74 (4): 281-286.

PIOTROWICZ-CIEŚLAK A.I. 2005b. Changes in soluble carbohydrates in yellow lupin seed under prolonged storage. Seed Sci. Tech. 33: 141-145.

ROBERTS E.H., ELLIS R.H. 1989. Water and seed survival. Ann. Bot. 63: 39-52.

ROBERTS E.H. 1972. Storage environment and control of viability. In: Viability of seed. Roberts E.H. (ed.), Syracuse, NY: Syracuse Univ. Press, 1972: 14-58.

ROBERTS E.H. 1973. Predicting the storage life of seeds. Seed Sci. Tech. 1: 499-514.

SALMONOWICZ B.P. 2000. Albuminy 2 S nasion u rodzaju $L u-$ pinus: polimorfizm, struktura i własności. Treat. Monogr. 9. Poznań pp. 110. (in Polish)

SHUTOV A.D., BAUMLEIN H., BLATNER F.R., MUNTZ K. 2003. Storage and mobilization as antagonistic functional constrains on seed storage globulin evolution. J. Exp. Bot. 54 (388): 1645-1654.

STANWOOD P.C., SOWA S. 1995. Evaluation of onion (Allium cepa L.) seed after 10 years of storage at $5,-18$ and $-196^{\circ} \mathrm{C}$. Crop Sci. 35: 852-856.

STEINER A.M., RUCKENBAUER P. 1995. Germination of 110year-old cereal and weed seeds, the Vienna Sample of 1877. Verification of effective ultra-dry storage at ambient temperature. Seed Sci. Res. 5: 195-199

SUN W.Q. 1997. Glassy state and seed storage stability: the WLF kinetics of seed viability loss at T- $\mathrm{T}_{\mathrm{g}}$ and the plasticization effect of water on storage stability. Ann. Bot. 79: 291-297.

SUN W.Q., LEOPOLD A.C. 1993. Acquisition of desiccation tolerance in soybean. Physiol. Plant. 87: 403-409.

VERTUCCI C.W. 1989. The effects of low water contents on physiological activities of seeds. Physiol. Plant. 77: 172-176.

WALTERS C. 2004. Temperature dependency of molecular mobility in preserved seeds. Anal. Biochem. 86: 1253-1258.

WILLIAMS R.J., LEOPOLD A.C. 1989. The glassy state in corn embryos. Plant Physiol. 89: 977-981. 